\title{
AKIBAT HUKUM PERJANJIAN MELALUI ELEKTRONIK DITINJAU DARI PASAL 1866 KITAB UNDANG-UNDANG HUKUM PERDATA
}

\author{
Nur Sa'adah, Sri Endah Indriawati \\ Fakultas Hukum Universitas Pamulang \\ E-Mail: dosen01383@unpam.ac.id
}

\begin{abstract}
Abstrak
Belum adanya undang-undang yang mengatur khusus data pribadi pengguna perjanjian melalui elektroni, menimbulkan sering terjadi permasalahan hukum baik menyangkut masalah keaslian, keotentikan sampai pembuktian. Penulisan ini memfokuskan pada permasalahan hukum yaitu bagaimana permasalahan terhadap keaslian, keotentikan dan integritas dari perjanjian secara elektronik dan bagaimana keabsahan dari suatu perjanjian yang dilakukan secara elektronik. Metode penelitian yang penulis gunakan adalah normatif kualitatif dengan menggunakan data sekunder dan diperkuat dengan data primer atau data lapangan. Hasil penelitian menunjukan bahwa Terhadap keaslian, keotentikan dan integritas dari perjanjian secara elektronik, dapat dilakukan dengan alat digital forensi. penggunaan informasi melalui media elektronik yang menyangkut data pribadi seseorang harus dilakukan atas persetujuan orang yang bersangkutan. Perjanjian yang dibuat melalui elektronik/digital mempunyai kekuatan pembuktian yang sama dengan perjanjian yang dilakukan melalui manual. Hakim bisa menggunakan sistem pembuktian dengan perkembangan kearah alat bukti terbuka. Alat bukti yang diperoleh dari mana saja asal bisa diterima kebenaran sepanjang tidak bertentangan dengan ketertiban umum, mengingat dalam bertransaksi di era digital saat ini kita akan sering menggunakan media online.
\end{abstract}

Kata Kunci: akibat hukum; perjanjian; melalui elektronik.

\section{Abstract}

The absence of a law that specifically regulates the personal data of users of the agreement via electronics, causing frequent legal problems both related to the problem of originality, authenticity up to evidencing. This writing focuses on legal issues, namely how the problems of theoriginality, authenticity and integrity of the agreement electronically and how is the validity of an agreement made electronically. The research method that I use is qualitative normative using secondary data and reinforced with primary data or field data. The results showed that the originality, authenticity and integrity of the agreement electronically, can be carried out by using digital forensi tools. The use of information through electronic media that involves a 
person's personal data must be done with the approval of the person concerned. The agreements made via electronic / digital have the same evidentiary power as agreements made manually. Judges can use a system of proof with developments towards open evidence. Evidence obtained from anywhere as long as truth can be accepted as long as it does not conflict with public order, considering that in doing transactions in the digital era today we will often use online media.

Keywords: legal consequences; agreement; via electronics.

\section{Pendahuluan}

Dewasa ini pemakaian internet sangat pesat, efek dari kemajuan dibidang tehnologi elektronik, perilaku masyarakat dunia dalam melakukan kegiatan baik dibidang perjanjian maupun kegiatan lain hampir semua dilakukan melalui elektronik. Seakan manusia dengan mudahnya melakukan hubungan hukum dengan manusia lain tanpa batas waktu dan wilayah. Melihat fenomena seperti itu aturan hukum dituntut untuk turun tangan, sehingga dalam melakukan transaksi secara elektronik dapat dicapai kata ketertiban dan kepastian dan keadilan bagi para pihak dalam melakukan transaksi melalui elektronik apapun bentuk transaksinya.

Apabila perjanjian sudah memenuhi persyaratan sahnya perjanjian, maka perjanjian tersebut mengikat kepada kedua belah pihak dan harus dilakukan dengan itikat baik. Dalam melakukan perjanjian maka harus terpenuhinya unsur- unsur sebagaimana disebutkan dalam Pasal 1320 KUHPerdata. Di dalam persidangan untuk memberikan kepastian kepada hakim maka kedua pihak harus bisa membuktian sesuatu yang benar-benar telah terjadi sehingga hakim merasa yakin bakwa apa yang dibuktikan itu adalah suatu yang benar. Inilah yang dinamakan dengan pembuktian.

Adanya keragaman mengenai hukum dan yuridiksi yang mengikat kedua belah pihak menimbulkan keraguan mengenai hukum dan yuridiksi hukum yang mengikat kedua belah pihak dalam melakukan perjanjian elektronik. Sampai sekarangmasih ada yang berpendapat bahwa perjanjian yang dilakukan secara elektronik tidak sah karena dianggap tidak nyata masih di dunia maya/ di angan-angan. Sebenarnya adanya perjanjian melalui elektronik berarti ada kedua belah pihak yang benar-benar ada bukan di dunia maya/ di angan-angan ${ }^{1}$.

Transaksi elektronik bisa langsung dilakukan oleh penjual dan pembeli atau bisa juga dilakukan dengan menggunakan perantara aplikasi yang tersedia

1 Daniel, Sitorus Alfredo "Perjanjian jual beli melalui internet (E-Commerce) di tinjau dari aspek hukum perdata, http://e-journal.uajy.ac.id/7998/1/JURNAL.pdf, diakses tanggal 24 Juli 2020 
dalam dunia maya, misalnya Tokopedia, Shopee dan Bukalapak. Dalam bertransaksi elektronik tersebut tentu saja tidak terlepas dengan adanya datadata yang secara elektronik diberikan, hal ini digunakan untuk memperlancar transaksi itu sendiri.Tentu saja data-data yang telah diberikan kepada provider aplikasi perantara transaksi elektronik merupakan data yang harus dilindungi oleh provider tersebut, karena jika data tersebut diketahui oleh pihak lain, transaksi akan menjadi tidak sesuai dengan apa yang diinginkan oleh pihakpihak yang bertransaksi. Kasus ini terjadi pada provider aplikasi perantara transaksi elektronik Bukalapak, yang mana ada 91 juta data pengguna aplikasi bocor ${ }^{2}$. Dalam sengketa ini tentu saja tidak terlepas dari penggunaan buktibukti elektronik baik dari pihak penggugat maupun pihak tergugat.

Dari contoh kasus tersebut dalam hal ini penulis akan membedah Pasal 1320 KUHPedata tentang syarat sahnya perjanjian , Undang-Undang Nomor 19 Tahun 2016 tentang Informasi dan Transaksi Elekronik kemudian Pasal 163 HIR jo Pasal 1866 KUHPerdata berkenaan dengan jenis-jenis alat bukti.

\section{Permasalahan}

Dengan mengacu pada latar belakang uraian di atas, maka perlu adanya suatu perumusan masalah untuk mempermudah proses pemecahan masalah yang diangkat dalan penelitian ini, yang pertama bagaimana permasalahan keaslian, keotentikan dan integritas dari perjanjian secara elektronik; kedua, bagaimana keabsahan dari suatu perjanjian yang dilakukan secara elektronik.

\section{Metode Penelitian}

Penelitian ini merupakan penelitian hukum sosiologis (socio-legal research), yang melihat hukum sebagai gejala sosial yang bersifat empiris. Penelitian ini untuk mengungkap permasalahan-permasalahan yang ada dibalik pelaksanaan dan penegakan hukum. Penelitian ini bersifat deskriptif, untuk mengumpulkan informasi mengenai status suatu variabel atau tema, gejala atau keadaan yang ada, yaitu keadaan gejala menurut apa adanya pada saat penelitian dilakukan. Penelitian ini mendeskripsikan pengaturan dan pelaksanaan keabsahan pembuktian perjanjian yang dilakukan secara elektronik ditinjau dari Pasal 1866 dan Undang-Undang ITE.

Data yang digunakan dalam penelitian hukum sosiologis (socio-legal research) ini adalah data sekunder dan diperkuat dengan data primer atau data lapangan. Adapaun data primer hasil wawancara dari Pejabat Kementrian Komunikasi dan Informasi dan Pengadilan Negeri Tangerang.

2 https://www.cnbcindonesia.com/tech/20200512133506-37-157889/buka-bukaanbos-tokopedia-soal-bocornya-91-juta-data-pengguna, diakses tanggal 20 Juli 2020 


\section{Pembahasan}

\section{Permasalahan Terhadap keaslian, Keotentikan Dan Integritas Dari Perjanjian Secara Elektronik.}

Salah satu "permasalahan terhadap keaslian, keotentikan dan integritas dari perjanjian secara elektronik" ialah membuktikan bahwa informasi atau dokumen tersebut otentik, misalnya: bagaimana membuktikan bahwa para pihak telah memberikan persetujuan secara elektronik dengan tanda tangan elektronik? Pengaturan bukti elektronik yang ada sampai saat ini baru dalam tataran hukum materiil saja, yaitu di dalam undang-undang Nomor 19 Tahun 2016 tentang Informasi dan Transaksi Elektronik ${ }^{3}$.

Hukum acara perdata di indonesia masih adanya permasalahan dalam hal hukum pembuktian secara elektronik yang berhubungan dengan tanda tangan elektronik pada dokumen. ${ }^{4}$ Menurut Arif Budi Cahyono hakim Pengadilan Negeri Tangerang saat diwawancara berkenaan dengan perjanjian melalui elektronik mengatakan bahwa :"Dengan adanya digital forensic. Digital forensik adalah metode yang digunakan untuk mengidentifikasi, mengumpulkan, menganalisa dan menguji bukti-bukti digital untuk suatu kasus hukum ${ }^{5}$.

Selanjutnya Arif Budi Cahyono hakim Pengadilan Negeri Tangerang saat diwawancara menambahkan bahwa, "Belum ada aturan hukum yang berhubungan dengan e-commerce. Saat ini menggunakan perjanjian baku "terms of agreement" yang ada di laman e-Commerce tersebut. Begitu kita klik "I accept", berarti kita sudah otomatis menundukan diri dan mengikatkan diri terhadap perjanjian serta peraturan dari e-Commerce yang kita gunakan. ${ }^{6}$

Lebih lanjut Arif Budi Cahyono menjelaskan bahwa : "Menurut MA, alat bukti elektronik masuk kedalam bukti petunjuk apabila dihubungkan kedalam Pasal 184 KUHAP . Yang perlu diperhatikan adalah apabila bukti elektronik dibantah oleh lawan. Nah maka dari itu kita menggunakan digital forensic untuk mengetahui otentisitas bukti tersebut. Misalnya foto bisa saja dirubah dan diedit. Disinilah peran digital forensik ini untuk menguji keautentikannya untuk memastikan bahwa foto tersebut diambil dari sumber apa dan asli tanpa editan. Contohnya adalah kasus Antasari dimana ada bukti dia sms an dengan pelaku, padahal menurut Pakar ITB itu bukan dikirim dari HP miliknya7. Provider bisa

${ }^{3}$ Theofanny Dotulong , Keberadaan Alat Bukti Elektronik Dalam Penyelesaian Sengketa Perdata, Jurnal Elektronik Bagian Hukum Keperdataan, Fakultas Hukum Universitas Sam Ratu Langi,No.3 Vol 2, Oktober 2014.

${ }^{4}$ Putri Visky Saruji, Nyoman A. Martana Kekuatan Hukum Pembuktian Tandatangan

Pada Dokumen Elektronik Sebagai Alat Bukti Dalam Hukum Acara Perdata Kertha Semaya : Journal Ilmu Hukum, Universitas Udayana, No.2 Vol 4, September 2015

${ }^{5}$ Arif Budi Cahyono hakim Pengadilan Negeri Tangerang, wawancara hari kamis tanggal 9 Juli 2020, jam 09.00 WIB.

6 Ibid

7 Ibid 
didefenisikan sebagai perusahaan atau badan usaha yang menyediakan layanan kepada pengguna. Provider terkadang juga bisa disebut sebagai Perusahaan yang biasanya melayani pembuatan website, mengatur penempatannya di dunia cyber (termasuk juga maintenance dan penyediaan akses Internet) juga membantu dari segi promosi agar website tersebut dikunjungi oleh pengguna Internet ${ }^{8}$.

Menurut Ruby Zukri Alamsyah seorang ahli forensik, mengungkapkan bahwa "Warga bisa melaporkan provider ke polisi bila terbukti ada oknum sipil bukan penegak hukum yang sengaja membocorkan data pribadi tanpa seizin pemiliknya", provider kena teguran ataupun sanksi dari BRTI (Badan Regulasi Telekomunikasi Indonesia). ${ }^{9}$

Josua Sitompul selaku Koordinator Hukum dan Kerjasama KOMINFO dalam jawaban atas pertanyaan Riset dan Penelitian kami menyebutkan bahwa "Elektronik mudah diubah, ditambah, atau dikurangi. Oleh karena itu, penerimaan informasi elektronik sebagai alat bukti yang sah (admissibility) ditentukan adanya kepastian bahwa informasi tersebut terjaga keotentikannya dan ketersediaannya. Arti dari otentik bukanlah informasi elektronik tersebut dibuat oleh pejabat yang berwenang. Setidaknya ada dua hal yang harus diperhatikan dalam menentukan keotentikan suatu informasi atau dokumen elektronik. Pertama, informasi elektronik disebut otentik dalam hal sumber informasi elektronik tersebut berasal dari orang atau pihak yang memiliki hak atau kewenangan untuk mengeluarkan informasi atau dokumen elektronik yang dimaksud. Kedua, konten atau isinya adalah konten yang dimaksudkan oleh sumber". ${ }^{10}$

Sebagaimana tertuang dalam Pasal 26 ayat (1) Undang-Undang Informasi dan Transaksi Elektronik yang menyebutkan bahwa: "Kecuali ditentukan lain oleh peraturan perundang-undangan, penggunaan setiap informasi melalui media elektronik yang menyangkut data pribadi seseorang harus dilakukan atas persetujuan Orang yang bersangkutan. Oleh karena itu apabila ada data pribadi dilanggar seperti kasus bocornya data pribadi maka pihak yang merasa haknya dilanggar dapat mengajukan gugagatan.

Pasal 5 ayat (1) UU ITE mengatur secara tegas bahwa Informasi atau Dokumen Elektronik dan/atau hasil cetaknya merupakan alat bukti hukum yang sah. Yang dimaksud dengan Informasi Elektronik ialah sebagaimana dimaksud dalam Pasal 1 butir 1 UU ITE. Sedangkan yang dimaksud dengan Dokumen

${ }^{8}$ https: / /idcloudhost.com/kamus-hosting/provider/, diakses tanggal 22 Juli 2020 https://mediaindonesia.com/read/detail/325719-data-seluler-bocor-warga-bisatuntut-provider-ke-polisi

10 Josua Sitompul, Koordinator Hukum dan Kerjasama, Kementrian Komunikasi dan Informatika Direktorat Jenderal Aplikasi Informatika Sekretaris Direktorat Jenderal Aplikasi Informatika, Jakarta, 11 Sepetember 2020 
Elektronik ialah sebagaimana diatur dalam Pasal 1 angka 4 UU ITE. Informasi dan dokumen elektronik dapat dibedakan tetapi tidak dapat dipisahkan. Secara sederhana, perbedaan Informasi Elektronik dan Dokumen Elektronik ialah bahwa Informasi Elektronik adalah data sedangkan Dokumen Elektronik ialah format dari data. Misalnya dalam file berbentuk .doc, .pdf, .mp3, dan .jpg maka Informasi Elektronik ialah kata-kata atau tulisan, huruf, angka yang terdapat dalam file tersebut. Sedangkan Dokumen Elektroniknya ialah .doc, .pdf, .mp3,.jpg.

Kemudian, Pasal 5 ayat (2) UU ITE mengatur bahwa Informasi Elektronik dan/atau Dokumen Elektronik dan/atau hasil cetaknya merupakan perluasan dari alat bukti yang sah sesuai dengan Hukum Acara yang berlaku di Indonesia. Pengaturan ini merupakan inovasi dalam UU ITE untuk menjembatani aturan dan prinsip lama mengenai alat bukti (yang harus dalam bentuk fisik) dan perkembangan teknologi.

Perluasan dari alat bukti yang sah dalam Hukum Acara Perdata mengandung makna: Memperluas cakupan atau ruang lingkup alat bukti yang diatur dalam Pasal 186 KUHPerdata, yaitu memperluas alat bukti tertulis atau surat. Dalam hal ini, perluasan tersebut merupakan hasil cetak dari informasi atau dokumen elektronik. Merupakan alat bukti lain, yaitu menambah jumlah alat bukti yang diatur dalam Pasal 186 KUHPerdata, yaitu informasi atau dokumen elektronik dan disebut sebagai alat bukti elektronik".

\section{Keabsahan Perjanjian Melalui Elektronik Ditinjau Dari Pasal 1866 KUHPerdata.}

Dengan adanya perjanjian maka menimbulkan akibat hukum yang masing-masing pihak wajib melaksanakan hak dan kewajiban karena telah menyetujui isi dari perjanjian tersebut, dimana hak dan kewajiban di dalam perjanjian dinamakan prestasi11. Akibat hukum dari perjanjian karena adanya perbuatan hukum, dimana perbuatan hukum itu terjadi karena ada pernyataan kehendak dari kedua belah pihak yang menimbulkan akibat yang diatur oleh hukum yaitu untuk melakukan hak dan kewajiban ${ }^{12}$.

Menurut Subekti bahwa "Suatu perjanjian adalah suatu peristiwa di mana seorang berjanji kepada seorang lain atau di mana dua orang itu saling berjanji untuk melaksanakan sesuatu hal". ${ }^{13}$ Berdasarkan Pasal 1313 KUHPerdata menyebutkan bahwa "Persetujuan adalah perbuatan dimana satu orang atau lebih mengikatkan dirinya terhadap satu orang lain atau lebih". Dalam Pasal

\footnotetext{
${ }^{11}$ Nur Sa'adah, Akibat Hukum Pembuktian Perjanjian Tidak Tertulis, Jurnal Pamulang Law Review, Fakultas Hukum Universitas Pamulang, No.2 Vol 1, November 2018

12 https://www.hukumonline.com/klinik/detail/ulasan/lt56751b3083cb0/perbedaanperdagangan-elektronik-dengan-transaksi-elektronik/, diakses 22 Juli 2020

${ }^{13}$ Subekti, Hukum Perjanjian, Intermasa, Jakarta, 2002. hlm.1
} 
1320 KUH Perdata disebutkan, untuk sahnya suatu perjanjian diperlukan empat syarat, yaitu: Sepakat mereka yang mengikatkan dirinya, artinya bahwa para pihak yang mengadakan perjanjian itu harus bersepakat atau setuju mengenai perjanjian yang akan diadakan tersebut, tanpa adanya paksaan, kekhilafan dan penipuan.

Ada 4 teori untuk mengatakan kesepakatan sudah tercapai yaitu : ${ }^{14}$ Teori Pengucapan; Teori Pengiriman;Teori Pengetahuan dan Teori Penerimaan Kecakapan untuk membuat suatu perikatan, artinya bahwa pihak-pihak yang akan membuat perjanjian harus yang cakap hukum, apabila adanya pihak-pihak tidak cakap hukum maka perjanjian tersebut dapat dibatalkan. Berdasarkan Pasal 1330 menyebutkan bahwa "Tak cakap untuk membuat suatu perjanjia adalah : Pertama, orang-orang yang belum dewasa, artinya bahwa orang-orang yang belum dewasa dilarang untuk membuat perjanjian, undang-undang mengatur bahwa yang termasuk orang-orang yang belum dewasa adalah mereka yang belum mencapai umur 21 tahun; Kedua; mereka yang ditaruh di bawah pengampuan, artinya bahwa orang-orang yang masih ditaruh di bawah pengampuan tidak bisa membuat perjanjian, seandainya membuat perjanjian maka diwakilkan oleh pengampunya; dan ketiga, orang-orang perempuan, dalam hal-hal yang ditetapkan oleh undang-undang, dan pada umumnya semua orang kepada siapa undang-undang telah melarang membuat perjanjianperjanjian tertentu, artinya bahwa perempuan termasuk orang-orang yang tidak cakap hukum, tetapi setelah undang-undang perkawinan lahir, maka aturan ini tidak berlaku. Undang-undang perkawinan mengatur bahwa perempuan termasuk subjek hukum yang cakap asal sudah dewasa dan tidak ada masalah lain. suatu hal tertentu artinya bahwa didalam perjanjian itu objek prestasi yang akan diberikan harus jelas dan pasti dan dapat digunakan oleh kedua belah pihak, buka masih dalam angan-angan atau masih direncanakan. Suatu sebab yang halal, artinya bahwa perjanjian sesuai dengan aturan-aturan hukum yang ada, tidak melanggar undang-undang, kesusilaan maupun ketertiban umum.

Perjanjian melalui elektronik juga diakui oleh United Convention on the Use of Elektronik Communication in International Contracts sebagaimana

\footnotetext{
14 Joni.R, Bambang, Hukum Ketenagakerjaan, Pustaka Setia, Bandung, 2013, hlm. 13.
} 
tertuang dalam Pasal 8 ayat (1) yang merupakan perjanjian yang mengikat dan sah menurut hukum. ${ }^{15}$

Josua Sitompul menyebutkan bahwa "Keabsahan hasil cetak dari informasi elektronik tergantung pada keabsahan informasi dan dokumen elektroniknya. Apabila informasi atau dokumen elektronik nya sah maka hasil cetaknya juga sah. Agar informasi atau dokumen elektronik sah, maka harus ada pemenuhan syaratan sebagai berikut 16

1. Pasal 5 ayat (4) UU ITE yang menegaskan bahwa surat yang menurut undang-undang harus dibuat dalam bentuk tertulis atau surat dan dokumen yang menurut undang-undang harus dibuat dalam bentuk akta notaril atau akta yang dibuat oleh pejabat pembuat akta. Dalam hal ini, bentuk elektronik dari surat atau dokumen tersebut tidak dapat dijadikan alat bukti hukum yang sah. Syarat formil yang diatur dalam KUHPerdata, ialah suatu akta dibawah tangan atau surat lainnya diakui oleh pihak yang berkepentingan.

2. Pasal 6 UU ITE, Informasi Elektronik dan/atau Dokumen Elektronik dianggap sah sepanjang informasi yang tercantum di dalamnya dapat diakses, ditampilkan, dijamin keutuhannya, dan dapat dipertanggungjawabkan sehingga menerangkan suatu keadaan.

3. Pasal 7 UU ITE, setiap Orang yang menyatakan hak, memperkuat hak yang telah ada, atau menolak hak Orang lain berdasarkan adanya Informasi Elektronik dan/atau Dokumen Elektronik harus memastikan bahwa Informasi Elektronik dan/atau Dokumen Elektronik yang ada padanya berasal dari Sistem Elektronik yang memenuhi syarat berdasarkan Peraturan Perundang-undangan.

Selanjutnya Josua Sitompul mengatakan bahwa” Berkaitan dengan tanda tangan elektronik, UU ITE dan PP 71/2019 mengatur adanya tanda tangan elektronik tidak tersertifikasi (misalnya dalam bentuk scan), dan tanda tangan tersertifikasi. Tanda tangan tersertifikasi menggunakan pihak ketiga yang terpercaya. Kedua jenis tanda tangan tersebut memiliki kekuatan hukum dan akibat hukum yang sah sepanjang ketentuan Pasal 11 UU ITE terpenuhi"17

Undang-Undang Telekomunikasi Nomor 36 Tahun 1999 Tentang Telekomunikas dalam Pasal 2 menyebutkan bahwa telekomunikasi diselenggarakan berdasarkan asas manfaat, adil dan merata, kepastian hukum,

${ }^{15}$ Dimas Prasojo, Hal-hal Penting Dalam Perjanjian Elektronik (Clik Wrap agreement), https://www.daya.id/usaha/artikel-daya/hukum-perizinan/hal-hal-penting-dalam-perjanjianelektronik-clik-wrap-agreement-, diakses tanggal 22 Juli 2020

16 Josua Sitompul, Op.Cit

${ }^{17}$ Ibid 
keamanan, kemitraan, etika, dan kepercayaan pada diri sendiri, Pasal 3 menyebutkan bahwa Telekomunikasi diselenggarakan dengan tujuan untuk mendukung persatuan dan kesatuan bangsa, meningkatkan kesejahteraan dan kemakmuran rakyat secara adil dan merata, mendukung kehidupan ekonomi dan kegiatan pemerintahan, serta meningkatkan hubungan antar bangsa.

Menurut Sudikno Mertokusumo bahwa "Pembuktian mengandung arti logis, konvensional dan yuridis. Dalam arti logis, adalah memberikan kepastian yang mutlak. Dalam arti konvensional berarti kepastian hanya saja bukan kepastian mutlak. Dalam arti yuridis, adalah Pembuktian yang memberikan kebenaran yang berlaku hanya bagi pihak-pihak yang berperkara". ${ }^{18}$

M. Yahya Harahap mengatakan bahwa "Yang dimaksud prinsip umum pembuktian adalah landasan penerapan pembuktian. Semua pihak, termasuk hakim harus berpegang pada patokan yang digariskan prinsip dimaksud. Memang di samping itu masih terdapat lagi prinsip-prinsip khusus yang berlaku untuk setiap jenis alat bukti, sehingga harus dijadikan patokan dalam penerapan sistem pembuktian. Namun apa yang dibicarakan dalam prinsip umum, merupakan ketentuan yang berlaku bagi sistem pembuktian secara umum". ${ }^{19}$

Menurut Arif Budiman hakim Pengadilan Negeri Tangerang saat diwawancara menjelaskan Pasal 5 ayat (1) Undang-Undang Informasi dan Transaksi Elektronok,menyebutkan bahwa: "Informasi Eletkronik dan/atau Dokumen Elektronik dan/atau hasil cetaknya merupakan alat bukti hukum yang sah". Selain itu, bukti elektronik membuka ruang bagi hakim untuk menerima alat bukti lain dan diakui sebagai alat bukti. ${ }^{20}$

Mengenai alat-alat, Hukum acara perdata di Negara kita mengenal alatalat bukti sebagaimana diatur didalam dalam Pasal 164 HIR dan Pasal 1866 KUHPerdata yaitu: Pertama, Tulisan; Kedua, Saksi; Ketiga, Persangkaanpersangkaan, Keempat; Pengakuan dan kelima, Sumpah.

Menurut M. Yahya Harahap bahwa " sistem pembuktian yang dianut sampai saat ini adalah sebagai berikut : Sistem Tertutup dan Terbatas Para pihak tidak bebas mengajukan jenis atau bentuk alat bukti dalam proses penyelesaian perkara. Perkembangan ke Arah Alat Bukti Terbuka Dalam hukum pembuktian tidak lagi ditentukan jenis atau alat bukti tertentu tetapi dari alat bukti mana saja pun harus diterima kebenaran sepanjang hal itu tidak bertentangan dengan ketertiban umum". ${ }^{21}$

18 Sudikno Mertokusumo, Hukum Acara Perdata Indonesia, Liberty Yogyakarta, 2006.hlm. 134-136.

${ }^{19}$ M. Yahya. Harahap, Hukum Acara Perdata, Sinar Grafika, Jakarta, 2005. hlm. 497-498.

${ }^{20}$ Arif Budi Cahyono hakim Pengadilan Negeri Tangerang, Op.Cit.

${ }^{21}$ M.Yahya. Harahap, Op.Cit, hlm. 554 - 556 


\section{Simpulan}

Informasi elektronik mudah diubah, ditambah, atau dikurangi. Oleh karena itu, penerimaan informasi elektronik sebagai alat bukti yang sah (admissibility) ditentukan adanya kepastian bahwa informasi tersebut terjaga keotentikannya dan ketersediaannya. Arti dari otentik bukanlah informasi elektronik tersebut dibuat oleh pejabat yang berwenang. Setidaknya ada dua hal yang harus diperhatikan dalam menentukan keotentikan suatu informasi atau dokumen elektronik. Pertama, informasi elektronik disebut otentik dalam hal sumber informasi elektronik tersebut berasal dari orang atau pihak yang memiliki hak atau kewenangan untuk mengeluarkan informasi atau dokumen elektronik yang dimaksud. Kedua, konten atau isinya adalah konten yang dimaksudkan oleh sumber. informasi elektronik yang diperlukan harus dapat diakses oleh para pihak termasuk pengadilan untuk kepentingan pembuktian. Dalam hukum perdata terdapat prinsip umum bahwa siapa yang mendalilkan ia harus membuktikan. Keabsahan dari perjanjian melalui elektronik diakui oleh undang-undang ITE yang merupakan informasi atau dokumen yang dilakukan melalui elektronik. Apabila terjadi perselisihan maka bisa dibawah ke jalur hukum, di mana kalau sampai kepersidangan hakim bisa menggunakan sistem pembuktian dengan perkembangan kearah alat bukti terbuka.

\section{Saran}

Kepada Lembaga Legislatif, Untuk perlindungan terhadap data pribadi sehingga dalam bertransaksi melalui elektronik ada kepastian hukum, maka perlu adanya Undang-Undang Perlindungan Data Pribadi. Kepada lembaga peradilan untuk memberikan adanya kepastian hukum khususnya terhadap alat bukti selain yang ada di Pasal 1866 KUHPerdata.

\section{Daftar Pustaka}

Buku

Joni. R Bambang, Hukum Ketenagakerjaan, Pustaka Setia, Bandung, 2013.

M. Yahya Harahap, Hukum Acara Perdata, Sinar Grafika, Jakarta, 2005.

Subekti, Hukum Perjanjian, Intermasa, Jakarta, 2002.

Sudikno Mertokusumo, Hukum Acara Perdata Indonesia, Liberty Yogyakarta, 2006. 
Jurnal

Theofanny Dotulong, Keberadaan Alat Bukti Elektronik Dalam Penyelesaian Sengketa Perdata, Jurnal Elektronik Bagian Hukum Keperdataan, Fakultas Hukum Universitas Sam Ratu Langi,No.3 Vol 2, Oktober 2014.

Nur Sa'adah, Akibat Hukum Pembuktian Perjanjian Tidak Tertulis, Jurnal Pamulang Law Review, Fakultas Hukum Universitas Pamulang, No.2 Vol 1, November 2018

Putri Visky Saruji, Nyoman A. Martana Kekuatan Hukum Pembuktian Tandatangan Pada Dokumen Elektronik Sebagai Alat Bukti Dalam Hukum Acara Perdata Kertha Semaya : Journal Ilmu Hukum, Universitas Udayana, No.2 Vol 4, September 2015.

Daniel Sitorus Alfredo "Perjanjian jual beli melalui internet (E-Commerce) di tinjau dari aspek hukum perdata, http://e journal.uajy.ac.id/7998/1/JURNAL.pdf, diakses tanggal 24 Juli 2020.

\section{Wawancara}

Arif Budi Cahyono hakim Pengadilan Negeri Tangerang, wawancara hari kamis tanggal 9 Juli 2020, jam 09.00 WIB

Josua Sitompul, Koordinator Hukum dan Kerjasama, Kementrian Komunikasi dan Informatika Direktorat Jenderal Aplikasi Informatika Sekretaris Direktorat Jenderal Aplikasi Informatika, Jakarta

Internet

https://www.cnbcindonesia.com/tech/20200512133506-37-157889/bukabukaan-bos-tokopedia-soal-bocornya-91-juta-data-pengguna,diakses tanggal 20 Juli 2020

https://tekno.kompas.com/read/2020/06/10/09144017/sidang-perdana-

kasus-kebocoran-data-tokopedia-digelar-hari-ini?page=all, diakses tanggal 20 Juli 2020

https://idcloudhost.com/kamus-hosting/provider/, diakses tanggal 22 Juli 2020

https: / /mediaindonesia.com/read/detail/325719-data-seluler-bocor-wargabisa-tuntut-provider-ke-polisi 
Dimas Prasojo, Hal-hal Penting Dalam Perjanjian Elektronik (Clik Wrap agreement ), https://www.daya.id/usaha/artikel-daya/hukumperizinan/hal-hal-penting-dalam-perjanjian-elektronik-clik-wrapagreement-, diakses tanggal 22 Juli 2020

Peraturan Perundang-undangan

Undang-Undang Telekomunikasi Nomor 36 Tahun 1999 Tentang Telekomunikasi. Undang-Undang Nomor 19 Tahun 2016 tentang Informasi dan Trasaksi Elektronik.

Undang-undang Nomor 16 tahun 2019 tentang Undang-Undang Perkawinan Kitab Undang-Undang Hukum Perdata.

HIR 